ARTICLE

Received 16 Nov 2015 | Accepted 31 Mar 2016 | Published 10 May 2016

DOI: 10.1057/palcomms.2016.15

OPEN

\title{
Science, technology and innovation indicators in policy-making: the Nigerian experience
}

Willie Siyanbola ${ }^{1}$, Adedamola Adeyeye ${ }^{2}$, Olawale Olaopa ${ }^{3,4}$ and Omowumi Hassan ${ }^{5}$

\begin{abstract}
This article provides a critical review of the process of formulating science, technology and innovation (STI) policy in Nigeria using scientific indicators. The attainment of development goals requires a painstaking process of policy-making based on scientific evidence derivable from relevant evidence. However, in many developing countries, there is a gap between policy and development priorities as most policies are not based on scientific facts either because they are unavailable or, where they exist, unreliable. Using a system analysis framework, the article brings into perspective the fundamental role played by STI indicators in providing scientific evidence for designing, formulating and implementing national innovation policy. This can serve as a framework for utilizing scientific evidence in policy-making in a developing country context. This article is published as part of a thematic collection on scientific advice to governments.
\end{abstract}

\footnotetext{
${ }^{1}$ Centre for Energy Research and Development, Obafemi Awolowo University, Ile-Ife, Nigeria ${ }^{2}$ National Centre for Technology Management, Obafemi Awolowo University, Ile-Ife, Nigeria ${ }^{3}$ Department of Political Science, Osun State University, Osogbo, Nigeria ${ }^{4}$ Department of Politics and International Relations, North-West University, Potchefstroom, South Africa ${ }^{5}$ High Tech Centre for Nigerian Women and Youths, Abuja, Nigeria
} 


\section{Introduction}

frica has been widely recognized as the poorest continent (World Bank, 1989, 2001, 2006; Mabogunje, 2004; Bigsten and Durevall, 2008; Ogbuji, 2009; Olaopa and Uzodike, 2009; Assefa, 2010). In 2005, the World Bank estimated the subSaharan Africa's (SSA) share of global Gross Domestic Product (GDP) as $1.4 \%$ despite contributing $11.5 \%$ of the world's population (World Bank, 2010). The continent faces overwhelming challenges that hamper its development. These include inadequate infrastructure, poor access to basic services, widening inequality, rising unemployment, conflicts, among others (MDGASG, 2008 cited in Assefa, 2010). The continent lacks the basic infrastructure to develop new technologies. Worse still, it lacks clear policy and capacity to adapt, absorb and diffuse imported technologies for her technological advancement (UNCTAD, 2007). To address these developmental challenges in Africa and other regions, governments, multilateral institutions and developmental partners set up the Millennium Development Goals (MDGs) and the successor, the Sustainable Development Goals (SDGs) (UN, 2015a). Central to the two are issues of eradicating poverty and hunger, achieving provision of quality education, clean water and sanitation, and promoting gender equality. In fact, one of the reasons for enacting the SDGs is because of the failure of many African countries to achieve some of the objectives, such as halving extreme poverty. For example, despite measurable improvements, more than $40 \%$ of SSA population, as at 2015, still live in extreme poverty. While gender parity has increased, the region still accounts for over half of the countries with gender disparity in primary education in 2012 (UN, 2015b). Given the above situation, one is therefore tempted to ask whether there is any chance for Africa to develop. If there is, what are the essential issues involved and that can guarantee sustainable development in Africa? Unobvious of the various contestations regarding the concept of development, within this article, the term sustainable development is taken to mean stable and continuous constructive socio-cultural, economic and political changes in the life of the people over a specific period of time (Olaopa et al., 2012) accompanied with their ability to create wealth and generate employment independently without any external interference (Akindele, 1995). The role of science and technology (S\&T) as an engine of development has been globally recognized (NEPAD OST, 2006; Chataway et al., 2009; NACETEM, 2010). Ilori (2002) posits that the application of S\&T increases the efficiency of production systems and enhances industrial competitiveness. In fact, what gives a nation competitive edge is the speed it can identify, utilize and diffuse new knowledge (Prusak, 1996).

However, for S\&T to translate to improved quality of life, wealth and employment creation, it must be focussed at bringing new goods and services in the market place. In other words, S\&T efforts must be geared towards innovation: the process of bringing new products to the market. Production systems in developed economies are been driven by the utilization of scientific and technological knowledge. There is therefore the need to put in place explicit strategies, mechanisms and institutions to translate scientific knowledge to development. This necessitates the formulation and regularly reviews of S\&T policies in driving sustainable development (Olaopa et al., 2011). How then could the sustainability of such development be assured in the context of a globalizing market economy and what role could science, technology and innovation (STI) indicators play in policy-making and sustaining such development? What would have been the priorities of STI in such a circumstance remained unanswered? In other words, the main question is: Do STI indicators play any role in policy-making and sustainable development? This article is therefore initiated to bringing to light the critical role of STI indicators for enhanced evidence-based STI policy-making and sustainable development. This is with a view to creating awareness on how STI policy can be effectively designed and implemented through the integration of scientific evidence to support the attainment of the national development agenda of a developing country using the experience of Nigeria. In doing this, we show bias for a qualitative research method and the secondary data were collected from the academic literature, magazines, newspapers, pamphlets, Internet-based information, including Websites and official documents on the subject matter and their contents were rigorously analysed.

Consequently, the article has been organized into five parts. First, the relationship between STI and development and the need for evidence-informed policy-making using STI indicators is emphasized. The second part examines the Nigerian experience in STI policymaking process using the system analysis framework. The third section outlines the lessons while the fourth expresses the limitation of using STI indicators. The paper ends with conclusions and policy recommendations.

\section{STI in development}

Knowledge, a product of science and scientific enterprise, is a key resource central to achieving development aspirations. While the term "development" is a universal concept, which often means different things to different people, the fact still remains that it is often used to denote social, economic and political conditions of the populace (Thomas, 2000). Any nation that fails to pursue development does so at its own peril. New knowledge unlocks opportunities that create new frontiers that in turn generate new knowledge (Metcalfe, 2000). As Knight (1935) cited in Metcalfe (2000) puts it, "in societies premised on the division of labour and the role of markets, economic development is a 'self-exciting' process". It is within the context of the creation and exploitation of new knowledge that the concept of STI in development situates. While knowledge accumulation is pivotal to development process, there is, however, no common agreement on the trajectory of the process; importantly, it is difficult to predict the outcome and consequences of exploitation of knowledge in development (Metcalfe, 2000). Despite this, developments in science may open up new opportunities for generating new ideas and knowledge that can only be translated to practical use and application by technology, which on the other hand is driven by the need and search for the underpinning natural principles for solving development challenges. In addition, there are differences in the nature of knowledge and also in the way knowledge is accumulated and applied to solve societal challenges among countries. These differences can be attributed to the strength and depth of their institutional structures for generating and applying knowledge.

Innovation, on the other hand, involves much more than idea and knowledge of relevant S\&T, but the application of that idea to the economic process (Wignaraja, 2003). While S\&T defines the accumulation and exploitation of knowledge to solve a given problem, innovation connects it to the market. In doing so, it is exposed to market factors, production principles, that are outside the scope of S\&T. Metcalfe (2000) however, identifies four factors that can shape innovation. These are opportunities, incentives, resources and managerial capabilities. They constitute the driving force behind any STI policy in that it not only addresses the concerns of S\&T but capabilities of firm to implement and market innovations and the factors that either enhance or obstruct them.

\section{Evidence-based policy: the missing link}

Driving economic growth and sustainable development through S\&T comes through a painstaking process of policy-making based on scientific evidences. The term evidence has been given different interpretations in the literature among different 
stakeholders such as researchers, policymakers, academics, among others. According to the UK Cabinet Office, the term includes a wide range of concepts such as expert knowledge; published research; existing research; stakeholder consultations; previous policy evaluations; the Internet; outcomes from consultations; costing of policy options; output from economic and statistical modelling (Cabinet Office, 1999). However, Sutcliffe and Court (2005) define evidence based on an output of a research process. Adopting the OECD's definition of research -that is any systematic effort to increase the stock of knowledge (OECD, 2002)-the authors define evidence as any scientific output that have been collected through a systematic process. These include the process of critical investigation and evaluation, theory-building, data collection, analysis and codification related to development policy and practice. Examples include statistical notions of evidence as well as qualitative techniques that determine under what condition a policy intervention will be effective (Sutcliffe and Court, 2005). It is within this context that we situate this article.

A good policy should address local challenges, devise clear and measurable strategies for achieving set objectives and garner the support of the stakeholders. It must also learn from previous experiences and leverage on scientific knowledge and facts. However, in many developing countries, there is a gap between policy and development priorities. Most policies are not based on scientific facts either because they are unavailable or where they exist, unreliable. In formulating STI policies, scientific indicators play a fundamental role of providing evidences for formulating national innovation strategies. The absence of relevant indicators is often a major obstacle for the design and implementation of STI policies in developing countries (NPCA, 2014). STI indicators are thus crucial in the innovation system. They are used to monitor the progress of the innovation system; evaluate the efficiency and effectiveness of allocated resources; and benchmark against set targets. Also, they can be used to forecast technological trajectories and thus provide a glimpse into the future (Gault, 2010). An indicator is defined as "a statistic, such as GDP, or population, or a combination of statistics, such as GDP per capita, which tells the public and the policy maker about the state of the economy and the society" (NEPAD, 2005). They provide opportunities for members of the public to participate in public policy debate, thereby serving as feedback to policymakers in the design and monitoring of evidence-based policy (NEPAD, 2005). Indicators become effective when they are rooted in the policy process, and are watered by continuous engagement between key actors including policymakers, statisticians and the public. They inform public policy debates and generate discussion within policy departments. Gault (2008) highlights two main objectives of using STI indicators in the policy process:

- Providing the Minister of S\&T with indicators and policy advice comparable to that received by the Minister of Finance;

- Presenting complex STI indicators in a way that is accessible to the policy community and to civil society.

In developed countries, organizations and bodies have been established with strong capacity for the collection, analysis and production of STI indicators to support evidence-informed policy. Such organizations include the OECD's Working Party of Network of Experts on Science and Technology Indicators; the European Union's Eurostat; UNESCO's Institute of Statistics (UIS); and the Network on Science and Technology Indicators (RICyT) in the Ibero-America and the Asia-Pacific Economic Cooperation and Pacific Economic Cooperation Council for the Asia-Pacific countries. These organizations provide services, undertake capacity-building, and conduct studies aimed at medium- to long-term planning (Pouris and Pouris, 2008). The need to develop STI indicators and enjoy its accrued benefits is not limited to developed countries; its importance was also recognized in the African Continent at the first NEPAD Ministerial Conference on Science and Technology as a means of assessing the African Peer Review Mechanism which among others monitors the success of African countries in the effort to commit 1\% of GDP to R\&D (Pouris and Pouris, 2008). But surprisingly, African countries, with the exception of few, are yet to build capacity for the development of STI indicators for integration into their policy process for enhanced national development. The reasons for this is connected with inadequate STI governance structure and STI advisory system, weak human capacity, poor state of STI infrastructure and inadequate funding to support STI activities (Siyanbola, 2013). Besides, the capacity of policymakers to provide balanced, comprehensive and timely information on policies relevant to S\&T has been limited by the lack of an effective knowledge transfer mechanism for disseminating and exploiting S\&T research outputs. This has been worsened by a communication gap between the National Assembly Committees on S\&T and knowledge institutions (NACETEM, 2011b). This missing link may account for the failure of their respective STI policy to harness their respective resources for sustainable development.

\section{Development of STI indicators project: the Nigerian experience}

In Nigeria, all the major stakeholders have realized the important role of S\&T in driving rapid industrialization and sustainable development. The government is also convinced that the attainment of sustainable development is predicated on the design of an appropriate policy framework based on effective knowledge and quality information. These are seen as the essential ingredients and indispensable requirements for policy-making. However, the depth, quality and reliability of existing knowledge and information in a society influence and determine the thoroughness, robustness and wholesomeness of its policies leading to increased efforts at leveraging on scientific evidence in the process of STI policy-making. This has motivated the country to intensify efforts at accessing quality and adequate information for effective STI policy-making. Specifically in Nigeria since the beginning of the current democratic governance, the source and quality of S\&T information available for decision-making is yet to be ascertained. Given the impact of S\&T knowledge on macroeconomic development, it is worthwhile to characterize the nature of S\&T information and its sources, and determine its impact on the policy-making process in Nigeria. The technological advancement of the country has been hindered by lack of an effective system of gathering scientific evidence that can be integrated into STI policy process. This led to the commencement of STI indicators project in 2005 with the objective of tracking the country's scientific growth and monitoring performance (NACETEM, 2011a). The initiative was later integrated into the New Partnership for Africa's Development, Office of Science and Technology (NEPAD OST), African Science, Technology and Innovation Initiatives (ASTII) in 2008. The Federal Ministry of Science and Technology was appointed as the Focal Point for Nigeria, while NACETEM was mandated to implement the programme on her behalf. Eighteen other African countries participated under the first phase of the project. The ASTII initiative provided the platform to undertake the first official Research and Development (R\&D) and Innovation Surveys in Nigeria. It also enabled African countries to use a uniform framework and methodology in developing policy-relevant surveys for Africa. This ensures comparability among member countries. The outcome provides 
a platform of integrating indicators into STI policy design with implications on sustainable development in developing countries like Nigeria. This is particularly important in view of the neglect of evidence-based research in decision-making processes in Africa (Olaopa et al., 2011). The Nigerian experience and the lessons learnt from the discussion of the next section.

\section{STI policy-making process in Nigeria: the history}

The realization of the role of S\&T in development led to the formulation of the first Nigerian National S\&T policy in 1986. It was aimed at giving direction to the pursuit of knowledge in S\&T by ensuring that knowledge is used to improve the welfare of the citizen. After about 10 years of its implementation, the government saw the need to incorporate new developmental issues in S\&T in a revised policy (FMST, 2011). The 1986 S\&T policy was revised in 1997 with a defined implementation time frame of 25 years, which is to be reviewed every 5 years (Olaopa et al., 2011). It aimed at creating an independent, integrated and self-sustaining economy. While giving prominence to issues of coordination, funding and collaboration, the 1986 S\&T policy lacks the structure to address the weak linkages in the National Innovation System (NIS). It also failed to exploit the opportunities of emerging technologies such as biotechnology, ICT and nanotechnology in solving societal challenges. These weaknesses and that of the 1997 version led to the formulation of a new policy in 2003. The new S\&T policy while addressing some of the failures of the predecessor was too narrow in focus, voluminous, sector-based and lacked the needed synergy with other national economic policies.

\section{The 2011 STI policy review: the major innovations}

The failure of most African countries to achieve sustainable development was compounded by African countries' lackadaisical attitude towards the application and utilization of scientific and technological knowledge for wealth creation and employment generation, as well as other social and economic objectives. To address this, government formulates policies as a course of action or inaction intended to accomplish a goal (Olaopa et al., 2011). Public policy is the output of the political system and it is made up of all the public decisions that governments authoritatively make. The objective of such policy is mainly to solve societal challenges in a fair and equitable manner. In doing this, the process of policy formulation and implementation or service delivery must be participatory in such a way that it is all-inclusive. The policy must be formulated by stakeholders based on consensus. This is to guarantee public ownership, effective participation, legitimacy, and ensure the responsiveness of public policies and institutions to societal needs (Agagu, 2010).

As a departure from previous S\&T policy documents, the new document, for the first time, integrates the concept of innovation to S\&T. This will help in achieving developmental objectives, especially government's economic agenda. In this sense, there is a swing in focus from knowledge generation to commercialization. This shift in paradigm is imperative in that new knowledge can be generated and deployed to produce goods and services, which will in turn lead to employment generation and wealth creation. In this regard, the policy process adopted a participatory (bottomup) approach by engaging various stakeholders in the country's NIS. They include FMST and agencies, cognate Ministries; the academia, including the Committee of Vice-Chancellors; Academies, including the Nigeria Academies of Science and Engineers; the business sector, including the Manufacturers' Association of Nigeria, and Lagos Chamber of Commerce and Industry; the Military; National Assembly; Development Partners: UNESCO,
UNDP, UNIDO and so on in the process leading to its formulation.

A major weakness of the S\&T policy formulation process in Nigeria is the non-utilization of scientific evidence in the process. To resolve this, the new STI policy, during its formulation process, leveraged on policy research outcomes, including, especially, R\&D and Innovation surveys, undertaken by NACETEM on behalf of the Nigerian government. Hence, using data from the surveys, the performance of the country was assessed and weak points identified and attended to. These areas include funding, governance structure, STI capacity-building and change in orientation from just knowledge accumulation to innovation.

\section{Strategic location of NACETEM within Nigeria's innovation system}

NACETEM plays a crucial role within Nigeria's NIS. It has a primary mandate of conducting policy research in STI management among others, thereby proving knowledge support to government. In line with this mandate, a number of key policy research projects and surveys have been undertaken successfully by NACETEM since 2005 in different areas of STI. These include energy and environment, ICT, policy review, innovation, entrepreneurship, indigenous technology, and R\&D and Innovation indicators. A key example is the development of STI indicators, which forms Nigeria's input into the NEPAD ASTII whose first edition was successfully completed in 2011. Also, deriving from its mandate, NACETEM led the effort at formulating the new STI policy for Nigeria, a process that was completed in 2012 (Siyanbola et al., 2012).

The crucial role of NACETEM in leading the two STI efforts of government-reviewing the STI policy and developing of STI indicators-is novel and strategic among African countries. The STI policy review process leveraged on the outcome of the STI indicators project. The timely, speedy and direct feedback of the indicators' output into the policy process was possible because NACETEM implemented the two projects. This is a model for African countries.

\section{Framework for policy formulation using STI indicators}

Theoretical framework. To understand the role of scientific evidence, in this case STI indicators, in the process of STI policy formulation and development, the article employs a systems framework.

The systems framework. The framework divides interaction process within a system into four phases, namely, input, conversion, output and feedback. Following the pioneering work of David Easton, the systems framework has been variously articulated and adapted for use in policy analysis by a number of scholars (see Dror, 1968; Bozeman, 1979; Anderson, 1984; Olugbemi, 1980; Henry, 1986; Egonmwan, 1991). All systems interact with and are influenced by their environment, although boundaries are defined for them so that they can be seen clearly and analysed (Koontz et al., 1980). The inputs pass through a conversion mechanism and the output is released into the environment (Olaopa, 2011). The output in turn has consequences both for the system and the environment in which the system exists (Easton, 1957).

In the context of this article, emphasis will be placed on how major stakeholders at every level of government work to influence STI decisions as a result of their position, ability, advantage, social role and structural pressures within which they operate. The point we are making here is that the activities of various actors, their socialization, orientation, their economic and political background, need to be closely examined to proffer reasons for 


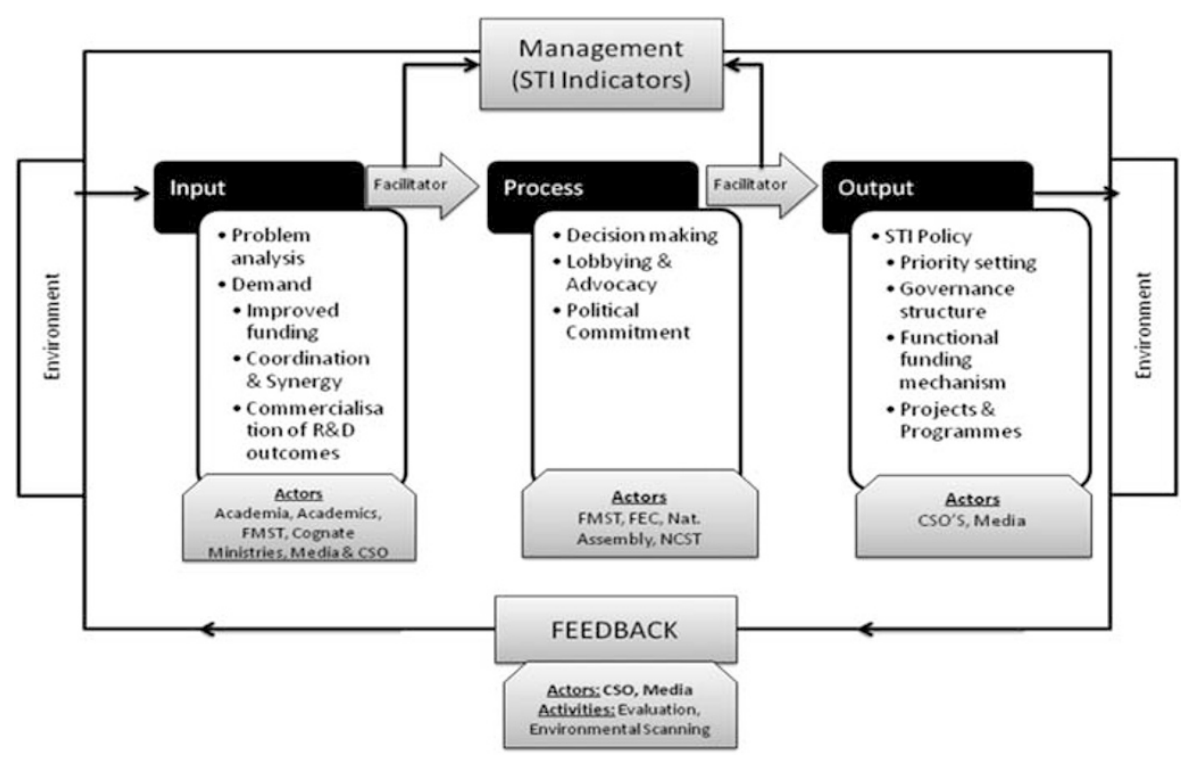

Figure 1 | Systems framework showing interrelationship between STI indicators and STI policy formulation process. Source: Olaopa (2011).

the effectiveness or otherwise of STI policy in Nigeria. The purposed actions of key stakeholders then becomes critical to the unravelling of the reasons for the success or otherwise of the formulation and implementation of any policy.

However, Nigeria has not been able to accord STI the required/ needed attention particularly in terms of funding with respect to $\mathrm{R} \& \mathrm{D}$ in the sharing of, and allocation of revenue due to lack of appropriate indicator that shows the implication of such action or inaction. This notwithstanding, various Governments have shown interest and increasing appreciation and understanding of the critical role of S\&T in the national political and socio-economic development programmes. In addition, they have at various times made efforts at establishing structures, formulating and designing policies to mobilize S\&T for rapid national development. These bold and deserving efforts have had limited success as the national S\&T system continues to suffer from major weaknesses and constraints as reflected by the inability of the respective policies to attain most of their objectives (Siyanbola et al., 2012). The reason for this includes, among others, lack of concrete evidence to provide the basis for their formulation. Thus, this underscored the need to provide evidencebased policy by leveraging on policy research outcomes, including, especially, R\&D and Innovation Surveys in line with global best practices. For instance, as earlier articulated in this article, the attainment of sustainable development is a function of an appropriately designed policy framework based on effective knowledge and quality information. However, lack of the depth, quality and reliability of existing knowledge and information that characterized previous S\&T policies has affected their thoroughness, robustness and wholesomeness. This has equally resulted in their limited operational performance.

We are not oblivious to the shortcomings of the systems framework, most especially its failure to focus only on the existence of parts that must work in harmony for the sustainability of the system without actually showing the roles/ functions that these parts must perform or be allocated (Olaopa, 2011) and the impediments to effective STI policy formulation, as well as their implications/consequences for effective operation of the National System of Innovation (NSI). The understanding of these roles/functions, the impediments to viable STI policy operation/performance and their accompanying consequences is very important in that their adequate performance or otherwise has a lot of implications on the entire socio-political system. These shortcomings, however, are not weighty enough to render this framework inappropriate for this article.

Figure 1 shows the complex web of influences and the almost multidimensional relationship that submerge the STI system in the process of making decision on STI development.

Feedback: Represents either positive or negative influence that the STI policy output (effective service delivery or otherwise) has upon the political system and its environment to shape subsequent inputs.

Environment: Includes (1) STI stakeholders (members of NSI), (2) members of the public and other government officials and those whose interest will be affected as a result of the implementation of the policy.

Inputs: These according to Easton (1957) consist of "demand, resource, support, opposition". As it relates to STI indicators and STI policy formulation in Nigeria, this includes the need and demand of Nigerian STI actors to have control over STI policy issues, the need for the policy researchers to provide resources, support and integrate evidence-based policy base on policy research outcomes. The demands include request for better funding, management of $R \& D$, mechanism for commercializing R\&D outcomes, human resource development, mechanism for S\&T acculturation, partnership, collaboration and science ethics, private-sector involvement, STI governance and administration, among others, as articulated by stakeholders in the NSI. These are fed into the policy-making machinery with the expectation that those who make policies will respond with policies, programmes or measures that would be implemented to meet those needs.

Process: $\quad$ This is also known as "withinput" or conversion box. They, according to Easton, consist of "structures, procedures, policymakers, psychosocial framework" (Ayodele, 2000). In this article, the process is the arena for the interplay 
of forces that result in policies-favourable or unfavourable-to STI development. It also involves various actors, including policymakers and stakeholders at all levels of government such as the President, Ministers and Commissioners for STI and related matters, Cognate ministries and their officials at all levels of government and other structure within which STI policies are made. Others include people, governments, businesses, and institutions of education, nongovernment organizations and other organized groups that have the capacity to engage in the activities of interest.

Outputs: $\quad$ These consist of "goods, services and symbols to public and other policymakers". In this article, they could be represented by STI policies that government formulates to promote efficiency and national development using STI indicators. These are implemented through projects, programmes and strategies. Thus, the extent to which the policy is effectively formulated with due regard to evidence will determine the effectiveness of the projects and programmes in solving developmental challenges.

Management: The overall coordination and management of the process driven by the use of STI indicators in the input, process, output and feedback. The capability of the government institute responsible for managing this will determine the extent to which the policy will address the needs of the stakeholders.

\section{Integrating STI indicators in policy-making: the how; the lessons}

The utilization of scientific evidence and inclusiveness in the process of formulating Nigeria's STI policy learnt credence to the integrity and wide acceptability of the process. Spanning a period of 24 months, the policy leveraged on the outcome of the STI indicators survey, which was coincidentally being completed when the policy-review process kicked off. The new policy benefitted from the outcome of the STI indicators project in the following ways.

From S\&T to innovation. The previous S\&T policies in Nigeria had their primary focus on the generation of knowledge for national development without focus on innovation and commercialization. The focus of most developmental plans of the country since the 1980s has been job and wealth creation, tackling unemployment and improving the standard of living of the people. This was emphasized in the National Development Plans of the 70s and 80s, NEEDS programme and, recently, the Vision $20 / 2020$. However, the S\&T policies were not designed to address these perhaps due to lack of appropriate indicator to show the critical need. This has led to a lacuna between the S\&T policy and the national plans and strategies. The main thrust of the 2012 exercise therefore shifts attention from just undertaking S\&T but innovation, a statement of intent redirecting S\&T to solving national economic challenges. This is why innovation was reflected in the title of the policy for the first time in Nigeria. This was enhanced by the country's involvement in the STI indicators project and the utilization of same in the review process, and thus represents a bold demonstration of the country's commitment at bridging the gap between S\&T and economic development. This has aligned S\&T with national development plan by refocusing R\&D and S\&T engagements towards entrepreneurship and innovation.

Shift in focus: from knowledge generation to wealth creation. The R\&D survey reveals that basic (36\%) and applied (38\%) research are the focus of Nigeria's $R \& D$ activities. Among the African countries that participated under the ASTII, Nigeria spent the highest on basic research, least on applied research and lower than South Africa, Malawi and Uganda on experimental development. This revelation by the STI indicators from the R\&D survey necessitated the shift in focus of the new policy from knowledge generation to employment generation and wealth creation. This will tackle one of the key challenges of the Nigerian economy; unemployment, which has a rate of about $24 \%$ in 2011 (NBS, 2011). To address this, the policy calls for shift of focus of research from basic to experimental development through technological entrepreneurship and innovation. It also calls for strengthening the curricula in technology entrepreneurship. Furthermore, it advocates for a strong linkage between the academia and the industry through the establishment of new and strengthening of the existing Intellectual Property and Technological Transfer Offices.

\section{Improved funding}

Creation of special funding agency. Although Nigeria's Gross Domestic Expenditure on R\&D (GERD) is second behind South Africa; however, when considered on a per capita basis, Nigeria occupies the 10th position. South Africa's per capita spending is about 26 times more than Nigeria's (AU-NEPAD, 2010). Only Mali and Mozambique spent less. More worrisome is the R\&D Intensity (GERD/GDP); a measure of the concentration of R\&D activities in an economy within a particular year. Nigeria ranks lowest among the 12 countries with a $R \& D$ intensity of 0.2 . This is far from the from the benchmark of $1 \%$ first agreed in the First Conference of Ministers Responsible for the Application of Science and Technology to Development in Africa (CASTAFRICA I) in 1974 in Dakar (UNESCO, 1987), and emphasized in various S\&T policy meetings and international declarations across the continent in the last 30 years. This includes the CASTAFRICA II, in Arusha in 1987, Lagos Plan of Action of 1980 and the Khartoum Declaration of the Executive Council of the AU in 2006 (UIS Bulletin, 2004; AU-NEPAD, 2010). Meeting this target will need a five-fold investment in R\&D. To tackle this, the new policy made case for improved funding for $R \& D$ in higher institutions and government. It thus advocated the creation of a special funding vehicle for R\&D-the National Research and Innovation Fund (NRIF). The aim is to create a competitive funding vehicle similar to the South Africa's National Research Foundation for funding R\&D in line with national priority.

Encouraging business sector funding. The trend in the developed and emerging economies is dominant business sector funding and performance of $\mathrm{R} \& \mathrm{D}$. Although government dominates $\mathrm{R} \& \mathrm{D}$ funding in most developing countries, the scenario is gradually changing towards the business sector. In 2007, the business sector accounted for $73.0 \%$ of GERD in South Korea (Park, 2010); 50.0\% in Brazil (OECD, 2010); 43\% in South Africa and 23\% in Malawi (AU-NEPAD, 2010). In Nigeria, as revealed by indicator from the R\&D survey, government is almost totally responsible for funding for R\&D activities with about $96 \%$ of the GERD. Among the 12 countries that undertook R\&D survey under the ASTII, Nigeria has the lowest contribution of private-sector funding contribution of about $1 \%$ (AU-NEPAD, 2010). Although the 
Nigerian business sector was not surveyed under the ASTII Initiative, however, there may not be significant difference in the outcome due to the nature of R\&D landscape in Nigeria. Most Nigerian firms lacked the capability to undertake R\&D, and in case of big companies and multinationals most of the R\&D activities take place outside the country (Egbetokun and Siyanbola, 2008). There are two major ways to encourage and motivate firms such that their capacity and capability to undertake $\mathrm{R} \& \mathrm{D}$ within the country can be improved. These include either levying of tax to generate more money to fund firms' in-house R\&D or providing tax incentives, in terms of tax holiday, for firms to do R\&D. The policy thus advocates a contribution of 5\% of Profit Before Tax, in line with the former option, to the NRIF by Nigerian business enterprises. Fiscal incentives such as tax rebates are suggested in the policy to encourage compliance.

Higher capability for STI. According to the Frascati Manual, researchers are professionals engaged in the conception or creation of new knowledge, products, processes, methods and systems and also in the management of the projects concerned (OECD, 2002). R\&D personnel, on the other hand, are all staff directly or indirectly involved in research. They include researchers and support staff such as technicians, administrative staff directly supporting R\&D. Researchers per million inhabitants in Nigeria is 119 , while that of R\&D personnel is 222 (AU-NEPAD, 2010). South Africa has 815 and 1,207, about seven and six times that of Nigeria, respectively. By implication, and has obviously revealed by researchers per million inhabitants, South Africa has more R\&D personnel than Nigeria. It then goes to show why South Africa has paid more attention to building capacity in the development and utilization of STI indicators in development process. These indicators are the basis upon which South Africa identifies priorities and directs their efforts at building up their basic STI statistical capabilities, foster the comparability of STI indicators and enhance their understanding of NISs. This revelation would have remained obscured without the scientific indicators. This necessitates the new policy to advocate the production of world-class scientists, engineers and technologists who are well grounded in theory, practice of basic sciences and the needs of entrepreneurship.

\section{Limitations of STI indicators in a developing country context}

From the above, it is clear that central to effective and efficient generation, exploitation and diffusion of knowledge is the appropriate measurement and management of STI using scientific evidence such as STI indicators. However, this is not to say that these indicators are perfect and that it is sufficient in providing the needed information for STI policy formulation. There are a lot of arguments regarding the shortcomings and limitations of STI indicators in policy-making process.

One major shortcoming is the neglect of framework for measuring innovation in the informal sector. This is in spite of the role the sector plays in developing countries, especially SSA. The informal sector is normally very large and includes a significant portion of the population in developing countries who, otherwise, are excluded from most economic activities Soremekun et al., 2014. It is a source of knowledge generation, diffusion of technologies, innovation and practices. The current STI Indicators do not acknowledge the importance of this sector in Africa, hence lack appropriate methodology for capturing them (Cozzens and Sutz, 2014). Information-gathering in this area cannot be sufficiently undertaken through conventional survey method but interviews, hence existing indicators may not sufficiently capture and account for or explain these. The same argument goes for indigenous knowledge in African countries, which could be used to provide medicines, improve agriculture and to promote local culture, but for which only interviews and case studies are required to lead to indicators (NEPAD, 2005). Similarly is the case of agriculture, which plays a dominant role in developing countries. In Nigeria, for example, the sector accounted for up to $40 \%$ the country's GDP in 2011 (NBS, 2012). Also, the sector employs about $70 \%$ of the national labour force in 2007 (NPC, 2009). Despite this, there are no standardized methodology and framework for measuring innovation in the sector (Kraemer-Mbula and Wamae, 2010).

Another limitation to the application of STI indicators in the design, implementation and evaluation of public policies is the timing of information. According to UNCTAD (2010), this issue is far more evident in the case of innovation surveys, where information is gathered once every 3 years, at best in contrasts with policy management, where decisions are taken almost on a daily basis. Moreover, as argued by UNCTAD (2010), STI indicators have emerged as distinct statistics from the general statistical strategy. Only a few countries have made efforts towards an integrated statistical database by making STI indicators a fundamental input for policy recommendations. This is lacking in most countries where there are significant conceptual and methodological difficulties for linking STI indicators withother economic indicators, thereby making it impossible to integrate them into national development plans (UNCTAD, 2010)

As earlier argued, for indicators to be used successfully, they must be embedded in the policy process that requires interaction between policymakers, who must be able to formulate objectives and statisticians, who formulate survey questions that provide information on the objectives formulated (NEPAD, 2005). It is sometimes difficult for this condition to be met or hold in many African countries. This is due to the existence of wide communication gap between the policymakers and other stakeholders in STI policy-making, thereby rendering the utilization of indicators ineffective. There is no doubt that indicators are useful tools for measuring and evaluating STI performance in any country or economy. However, as discussed above, they require a capacity to formulate questions and to design surveys that yield useful information, and that can be analysed to produce indicators. This is in short supply in most African countries as previously noted, thus limiting the application of STI indicators in policy process.

However, for a country like Nigeria and most countries in SSA, the opportunity to develop comparable and relevant indicators represent a milestone in the process of integrating scientific evidence in governance. Hence, the shortcomings and limitations notwithstanding, the critical role of STI indicators in guaranteeing evidence-based policy-making cannot be neglected.

\section{Conclusions and policy recommendations}

In the twenty-first century economy, organizations and governmental institutions depend on knowledge to strategically achieve corporate and governance objectives. Knowledge, as the foundation of an institution/organization's competitive advantage, its exploitation and commercialization, drives organization's value (Grant, 1996). In other to achieve this, it is imperative that the process of knowledge exploitation and commercialization needs to be continuously monitored and assessed. In addition, there is a need to consistently benchmark against set targets and goals so as to track progress. The development and integration of scientific evidence like STI indicators makes this possible. More importantly, it will assist in the formulation of an efficient STI policy for economic growth and sustainable national development. It is the 
realization of this that made Nigeria to deploy, to a greater effect, STI indicators to re-shape the content, quality and even structure of the new STI policy. Future expectations are that it will have similar impact on other key sectoral policies like education, agriculture, health, energy and environment, ICT, trade and investment, SMEs and the overall economic and development programmes of government. There is also the need to embark on strategic popularization, sensitization and advocacy among stakeholders in government and the private sector. However, to achieve better impact in the use of STI indicators in development, we propose that experts consider the following recommendations.

Constructing a strategic system framework for STI indicators. STI indicators cannot exist in a vacuum. To enhance policy process they must be integrated in to the entire socio-economic and political systems. The understanding of this helps policymakers to change the system. Therefore, a basic framework is required to support this understanding and capacity to act in the areas of STI. What we have outlined in this article is an outline of such a framework that offers a guide in developing country context. This will assist in building STI indicators as a fundamental input for policy recommendations into the general statistical set or database, on the one hand, and in the effective understanding of scientific, technological and organizational change, and its accompanying social and economic impact, on the other.

Integrating STI indicators into the policy process. The procedure of integrating STI indicators in policy process requires effective collaboration and interaction between policymakers and major stakeholders. Effective STI indicators, as argued, should capture the processes of generation, diffusion and appropriation of knowledge in the NIS. Although some improvements have been made using output indicators (bibliometric, patent and innovation indicators), this notwithstanding, very little is still known about the dynamics of the system as a whole (UNCTAD, 2010). As earlier asserted, the level of interaction among the STI actors in the NIS is very low in many of the African countries due to lack of information. To resolve this, there is the need to direct effort towards the identification and characterization of the various actors and stakeholders in the NIS, their knowledge, capabilities and expected roles, how they interact or should interact and whether STI is generating the expected impact to make effective utilization of indicators in policy-making process.

Building requisite and appropriate STI capacity and capability. For STI indicators to be a useful tool for measuring and evaluating STI performance in any country or economy, there is need to build requisite and appropriate STI capacity and capability. More knowledge institutions where experts will be trained should be established, while the existing ones should be strengthened. Specifically, policy on capacity-building should not be a general one but one that is directed at solving specific problem. For instance, while indicators might reveal the need to increase the stock of qualify human resources related to and sciences, technology and engineering, there is also the need for efforts to know about the degree choices of students based on secondary or middle education statistics and the exact numbers of each disciplines that is required. In other words, efforts should be made in developing indicators capable of linking S\&T dynamics with specific needs and national priorities.

Linking STI indicators with national development goals or aspiration. To mitigate the problems posed by low technological development and lack of capacity to absorb imported technologies, governments of developing and developed countries set up the MDGs and the successor, the SDGs. Central to the two are issues of eradicating poverty and hunger, achieving provision of quality education, clean water and sanitation, and promoting gender equality. To really achieve the proper resolution of these problems, efforts should therefore be aligned towards the creation of national and regional indicators capable of identifying and measuring not only the mechanism but also the extent to which STI is contributing towards these goals.

Framework for designing and gathering data on innovation in informal and agricultural sectors. Given the fact that information-gathering, with respect to STI indicators and practices, in the informal and agricultural sector is difficult relying on conventional survey methods, there is need for a paradigm change in information-gathering that gives cognizance to the peculiarities of African societies and economies. In doing this, governments must embark on strategic popularization, sensitization and advocacy among stakeholders in government and the private sector.

\section{References}

Agagu AA (2010) Governance and public policy in Nigeria. In: Omotoso F, Agagu $\mathrm{AA}$ and Abegunde $\mathrm{O}$ (eds). Governance, Politics and Policies in Nigeria: An Essay in Honour of Professor Dipo Kolawole. Editions SONOU d'Afrique: Benin Republic, West Africa, pp 38-53.

Akindele ST (1995) Political mobilisation for rural development and a stable Nigerian democratic republic. In: Akindele ST and Ajila CO (eds). Contemporary Issues in the Social Sciences. Transcradle: Ile-Ife, pp 112-136

Anderson J (1984) Public Policy Making. Holt, Rinehart and Winston: New York. Assefa T (2010) Enabling knowledge sharing to promote innovative organizations in Africa. A paper to be presented at Expert Group Meeting on Harnessing Knowledge to Achieve MDGs, 4-5 November, Addis Ababa, Ethiopia.

AU-NEPAD. (2010) African Innovation Outlook 2010. AU-NEPAD: Pretoria, South Africa.

Ayodele JO (2000) The relevance of physician training to PHC (Primary Health Care) in Nigeria. Unpublished $\mathrm{PhD}$ thesis submitted to the Department of Sociology and Anthropology, Obafemi Awolowo University, Ile-Ife, Nigeria.

Bigsten A and Durevall D (2008) The African Economy and Its Role in the World Economy. Elanders Sverige AB: Uppsala, Sweden.

Bozeman B (1979) Public Management and Policy Analysis. St. Martin's Press: New York, p 309.

Cabinet Office. (1999) Modernising Government. The Stationery Office: London.

Chataway J, Chatuverdi K, Hanlin R, Mugwagwa J, Smith J and Wield D (2009) Technological Trends and Opportunities to Combat Diseases of the Poor in Africa (Chapter 2). In: Kalua FA, Awotedu A, Kamwanja LA and Saka JDK (eds). Science, Technology and Innovation for Public Health in Africa. Monograph, NEPAD Office of Science and Technology, Republic of South Africa, Pretoria, South Africa.

Cozzens S and Sutz J (2014) Innovation in informal settings: Reflections and proposals for a research agenda. Innovation and Development; 4 (1): 5-31.

Dror Y (1968) Public Policy Making Re-Examined. Chandler: San Francisco, CA.

Easton D (1957) An approach to the analysis of political systems. World Politics; 9 (3): 38-400.

Egbetokun AA and Siyanbola WO (2008) On the link between science, technology, innovation and development: What matters for African nations. Paper presented at the Science with Africa Conference organised by the United Nations Economic Commission for Africa (UNECA), 3-7 March, Addis Ababa, Ethiopia.

Egonmwan JA (1991) Public Policy Analysis: Concepts and Applications. S.M.O Aka and Brothers Press: Benin City, Nigeria.

Federal Ministry of Science and Technology (FMST). (2011) Nigeria Science, Technology and Innovation Policy. FMST: Abuja.

Gault F (2008) Science, technology and innovation indicators: Opportunities for Africa. African Statistical Journal; 6 (May): 141-162.

Gault F (2010) Innovation Strategies for a Global Economy: Development, Implementation Measurement and Management. IDRC.

Grant RP (1996) Toward knowledge based theory of the firm. Strategic Management Journal; 17 (S2): 109-121.

Henry N (1986) Public Administration and Public Affairs, 3rd edn. Prentice-Hall: Englewood Cliffs, NJ, p 249.

Ilori TA (2002) Promoting technological innovation for the industrial development of Africa. NISER Monograph Series No 6. NISER: Ibadan. 
Kraemer-Mbula E and Wamae W (2010) Innovation and the Development Agenda. OECD/IDRC: Paris, France.

Koontz H, O'Donnell C and Weihrich H (1980) Management, 7th edn. McGrawHill International Book Company: Japan, p 70

Mabogunje AL (2004) Framing the fundamental issues of sustainable development in Sub-Saharan Africa. CID Working Paper No. 104. Cambridge, MA: Sustainable Development Program, Center for International Development, Harvard University; also published as TWAS Working Paper 1. Third World Academy of Sciences: Trieste, Italy.

MDG Africa Steering Group (MDGASG). (2008) Achieving the millennium development goals in Africa recommendations of the MDG Africa Steering Group, http://www.mdgafrica.org/pdf/MDG Africa Steering Group Recommen dations - English - HighRes.pdf, accessed 11 June 2010.

Metcalfe JS (2000) Science, technology and innovation policy in developing economies. Fourth Draft 21st July. Paper prepared for the workshop on Enterprise Competitiveness and Public Policies, Barbados, 22-25 November, 1999.

NACETEM. (2010) Assessment of innovation capability in the manufacturing sector in Nigeria. Monograph Series No 4: NACETEM: Ile-Ife.

NACETEM. (2011a) Report of 2006/07 R\&D Survey (1st edition). NACETEM: Ile-Ife.

NACETEM. (2011b) Evaluation of the source and quality of S\&T knowledge available to Ministry Staff and National Assembly. A research report. National Centre for Technology Management (NACETEM), Federal Ministry of Science and Technology, Nigeria. Funded by the International Network for the Availability of Scientific Publications (INASP).

NBS. (2011) The 2011 annual socio-economic report, http://www.nigerianstat.gov. ng/pages/download/38, accessed 14 August 2012.

NBS. (2012) Q1-Q4 2011 and Q1 2012 gross domestic product for Nigeria, http:// www.nigerianstat.gov.ng/pages/download/72, accessed 26 August 2012.

NPC. (2009) Report of the Vision 2020 National Technical Working Group on agriculture \& food security, http://www.npc.gov.ng/vault/NTWG\%20Final\% 20Report/agriculture\%20\&\%20food\%20security\%20ntwg\%20report.pdf, accessed 27 August 2012.

NEPAD. (2005) African Science, Technology and Innovation Indicators (ASTII), Towards African Indicator Manuals. A Discussion Document. http://www. nepadst.org/doclibrary/pdfs/iastii_jun2006.pdf, accessed March 2009.

NEPAD OST. (2006) Africa's Science and Technology Consolidated Plan of Action. NEPAD OST: Pretoria, South Africa.

NEPAD Planning and Coordinating Agency (NPCA). (2014) African Innovation Outlook 2014. NPCA: Pretoria, South Africa.

OECD. (2002) Frascati Manual: Proposed Standard Practice for Surveys on Research and Development. OECD: Paris, France.

OECD. (2010) OECD Science, Technology and Industry Outlook, OECD Publishing, http://dx.doi.org/10.1787/sti_outlook-2010-en, accessed 3 January 2012.

Ogbuji K (2009) Gaddafi and the United States of Africa. Triumph Newspaper, 2 February.

Olaopa OR (2011) The politics of local government financing in Southwestern Nigeria, 1999-2009. An unpublished research thesis submitted to the School of Politics in fulfilment of the requirements for the award of Doctor of Philosophy in public policy. School of Politics, University of KwazuluNatal, South Africa.

Olaopa OR and Uzodike U (2009) Science, Technology and Innovation (STI) Promotion: An imperative for youth empowerment for Africa's development. An unpublished paper presented at the Joint AISA/SAAPS Symposium on Defining the Contours of Knowledge Production in the 21 century organised by the Africa Institute of South Africa (AISA) in association with the South African Association of Political Science (SAAPS) on 15 and 16 October at Burgers Park Hotel, Tshwane, South Africa.

Olaopa OR, Akindele ST; and Hassan OM (2011) Science and technology research: Repositioning the thinking of policy makers in Nigeria. African Journal of Science, Technology and Innovation Development; 3 (1): 202-225.

Olaopa OR, Uzodike U, Siyanbola OW and Franci S (2012) Positioning and strengthening Africa's development through innovative educational policy on STI. In: Bokemann W, Akinwumi O, Nwankwo UM and Agwuele AO (eds). African Leadership Challenges and Other Issues in Contemporary African Countries. MediateamIT education Center: Berlin, German. Chap. 9, pp 111-130.

Olugbemi SO (1980) A systems approach to intergovernmental relations (IGR). Quarterly Journal of Administration; Xiv (2): 110-117.

Park HS (2010) Dynamic evolution of Korean science and technology. A presentation at the R\&D Management Programme for High Level Policy Makers organised by the Korean Institute of S\&T Evaluation and Planning (KISTEP) under the UNESCO-ISTIC South South Cooperation Programme, 7-12 November, Cairo Egypt.

Pouris A and Pouris A (2008) The state of science and technology in Africa (20002004): A scientometric assessment. Scientometrics; 79 (2): 297-309.

Prusak L (1996) The knowledge advantage. Planning Review; 24 (2): 6-8.

Siyanbola WO, Olaopa OR; and Hassan WO (2012) Designing and implementing a Science, Technology and Innovation (STI) policy in a developing country context: Recent experience from Nigeria. The 10th Triple Helix International Conference. Conference Proceeding, Panghegar, Bandung, 8-10 August.

Siyanbola WO (2013) Beyond the figures: Deploying STI indicators for policymaking and national planning. Paper presented at the ASTII HighPanel Meeting on the Draft R\&D Surveys Guide and In-country ASTII Training Workshop, Kigali, Rwanda, 5-9 August.

Soremekun AJ, Ajao BF, Jegede OO and Egbetokun AA (2014) Innovation systems in developing countries: stylized facts and research issues. Paper presented at the 12th GLOBELICS Conference, Addis Ababa, Ethiopia. 29th31st October, 2014. http://www.slideshare.net/adekemioluwadare/towardsthe-future1-2.

Sutcliffe S and Court J (2005) Evidence-Based Policymaking: What is it? How Does it Work? What Relevance for Developing Countries? Overseas Development Institute. https://www.odi.org/sites/odi.org.uk/files/odi-assets/publications-opi nion-files/3683.pdf, accessed 15 February 2016.

Thomas A (2000) Meanings and views of development. In: Allen T and Thomas A (eds). Poverty and Development in the 21st Century. Oxford University Press: Milton Keynes, UK.

United Nations. (2015a) Transforming our world: The 2030 agenda for sustainable development. Resolution adopted by the General Assembly on 25 September, http://www.un.org/ga/search/view_doc.asp?symbol = A/RES/70/1\&Lang $=\mathrm{E}$, accessed January 2016.

United Nations. (2015b) Time for global action for people and planet. United Nations Millennium Development Goals Report.

UNCTAD. (2007) United Nations conference on trade and development: The least developed countries report 2007. United Nations: Geneva, Switzerland, http:// www.unctad.org/en/docs/ldc2007_en.pdf, accessed 6 June 2010.

UNCTAD. (2010) United Nations conference on trade and development: Science, technology and innovation indicators for policymaking in developing countries: An overview of experiences and lessons learned. Note prepared by the UNCTAD secretariat (Geneva, 11 January). TD/B/C.II/MEM.1/CRP.1. Downloaded in 17 February 2016

UNESCO. (1987) Second conference of ministers responsible for the application of science and technology to development in Africa (CASTAFRICA II), Special Programme of Assistance to Africa in the Fields of Scientific and Technological Research and of Research and Development, 6-15 July, Arusha, Tanzania; Paris, France.

UIS (UNESCO Institute of Statistics Bulletin on Science and Technology Statistics). (2004) A decade of investment in research and development (R\&D): 1990-2000: Issue No. 1, April.

Wignaraja G (2003) Competitiveness Strategy in Developing Countries: A Manual for Policy Analysis (Vol. 30). Routledge.

World Bank. (1989) Sub-Saharan Africa: From crisis to sustainable growth-A long-term perspective study. The World Bank: Washington DC, cited in Mabogunje, AL (2004). "Framing the Fundamental Issues of Sustainable Development in Sub-Saharan Africa". CID Working Paper No. 104. Sustainable Development Program: Cambridge, MA, Center for International Development, Harvard University; also published as TWAS Working Paper 1. Third World Academy of Sciences: Trieste, Italy.

World Bank. (2001) African Poverty at the Millennium: Causes, Complexities and Challenges. The World Bank: Washington DC.

World Bank. (2006) World Development Report 2007: Development and the Next Generation. World Bank: Washington DC.

World Bank. (2010) World development indicators (WDI), http://data.worldbank. org/data-catalog/world-development-indicators, accessed 11 June 2010.

\section{Data availability}

Data sharing is not applicable to this article, as no datasets were generated or analysed during the current study.

\section{Additional Information}

Competing interests: The authors declare no competing financial interests.

Reprints and permission information is available at http://www.palgrave-journals.com/ pal/authors/rights_and_permissions.html

How to cite this article: Siyanbola W, Adeyeye A, Olaopa O and Hassan O (2016) Science, technology and innovation indicators in policy-making: the Nigerian experience. Palgrave Communications. 2:16015 doi: 10.1057/palcomms.2016.15.

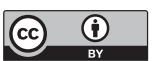

This work is licensed under a Creative Commons Attribution 4.0 International License. The images or other third party material in this article are included in the article's Creative Commons license, unless indicated otherwise in the credit line; if the material is not included under the Creative Commons license, users will need to obtain permission from the license holder to reproduce the material. To view a copy of this license, visit http://creativecommons.org/licenses/by/4.0/ 